\title{
Effect of polyethylene mulching type on the growth, yield and fruits quality of physalis pubescens
}

\begin{abstract}
This investigation was carried out in a private farm located at Shebeen El-Qanatir city, El-Qaliubiya governorate, Egypt during the two successive seasons (2011/2012 and 2012/2013 A.D.) to study the response of husk tomato plants (Physalis pubescens L.) $\mathrm{cv}$. (local variety) to polyethylene mulching black and double face (white on black). A bare soil plot of equal area was also maintained with raised beds un-mulched as a control. Seedlings were transplanted forty days after sowing into open field transplanting carried out in $60 \mathrm{~cm}$ apart on the row among plants. Results showed that the significant maximum value of plant height, stem diameter, number of branches per plant and leaf area were obtained from white on black mulching treatment followed in a descending order by black treatment, while bare soil treatment recorded the minimum significantly value in both seasons. Results appeared that the significant maximum value of total soluble solids, vitamin $\mathrm{C}$, total sugar and total carotenoids were obtained from white on black mulching treatment followed by black treatment, while bare soil treatment recorded the minimum value in both seasons. On the other hand, no significant different for total acidity and dry matter were recorded among mulching treatments in both seasons. Results appeared that the significant maximum value of number of fruit/ plant, total yield and early yield per plot were obtained from (white on black) mulching treatment followed in a descending order by black treatment, while bare soil treatment recorded the minimum value in both seasons.
\end{abstract}

Volume 6 Issue 5 - 2017

\author{
Helaly AA,' Goda Y,' Abd El-Rehim AS, ${ }^{2}$ \\ Mohamed AA,' El-Zeiny OAH ${ }^{2}$ \\ 'Horticulture Department, Faculty of Agriculture, Al-Azhar \\ University, Cairo, Egypt \\ ${ }^{2}$ Horticulture Research Institute, Ministry of Agriculture, Giza, \\ Egypt
}

\begin{abstract}
Correspondence: Helaly AA, Department of Horticulture, Faculty of Agriculture, Al-Azhar University, Cairo, Egypt, Email alaahelaly@hotmail.com
\end{abstract}

Received: December 28, 2016 | Published: March 15, 2017

Keywords: physalis pubescens, growth, polyethylene mulching, yield, TSS, total sugars, vitamin $\mathrm{C}$

\section{Introduction}

Husk tomato (Physalis pubescens L.) is one of the most important vegetable crops in Egypt. The husk tomato belongs to the nightshade family (solanaceae). The genus Physalis, established by Linnaeus in 1753 , contains about 463 species but 100 species are well known and have more fanciful names such as husk tomato, golden berry, ground cherry, strawberry tomato, Cape gooseberry and pubescent ground cherry. ${ }^{1,2}$ Physalis has been known in Egypt since the sixteen century under the name of its varieties 'Harankish', 'Halawyat' and 'El-Set El-Mestihya'. Because the fruit is covered in papery husk; giving it its name. ${ }^{3}$ Husk tomato plants produce small orange fruits similar in size and shape to a cherry tomato. It is a highly nutrition fruit; low in fat and contains no cholesterol or sodium. Husk tomato fruits provide an excellent source of the vitamin A and C, minerals (phosphorus and iron), protein, carotene, sugars and organic acids because of this they are a good choice for making health. ${ }^{4}$

Polyethylene is one of the most commonly used plastic materials for mulching, due to the fact that it is easy to process, has excellent chemical resistance, high durability, flexibility and is odorless as compared to other polymers. It forms a relatively impermeable vapor barrier on the soil surface, changing the pattern of heat flow and evaporation. ${ }^{5}$ The use of plastic mulch in agriculture has increased dramatically in the last 10years throughout the world. This increase is due to benefits such as increase in soil temperature, reduced weed pressure, moisture conservation, reduction of certain insect pests, higher crop yields, and more efficient use of soil nutrients. ${ }^{6}$ Plastic mulches directly affect the microclimate around the plant by modifying the radiation budget of the surface and decreasing the soil water loss, resulting in more uniform soil moisture. The soil temperature in the planting bed is raised, promoting faster crop development and earlier harvest. ${ }^{8}$ Mulching decreases the fluctuations in temperature in the first $20-30 \mathrm{~cm}$ depth in soils and promotes root development reduces vegetative competition in the rooting zone reduces fertilizer leaching and soil compaction, and the vegetable productions are cleaner since no soil is splashed onto the plants or fruits. ${ }^{9}$

So the soil under plastic mulch remains loose, friable and well aerated. Roots have access to adequate oxygen, and microbial activity is enhanced. ${ }^{10}$ There are three primary non-degradable mulch colors used commercially in the production of vegetable crops: ${ }^{9}$ black, clear and the group of white, white-on-black reflective mulches. Black polyethylene is the most popular because it prevents weed growth in addition to its low cost. Clear mulch provides an even warmer soil environment than black plastic mulch, but requires the use of another technique to control weeds (herbicide, soil fumigant or solarization). White, white on-black reflective mulches can result in a slight increase or even a slight decrease in soil temperature compared to bare soil, tending to minimize changes in soil temperature, because they reflect back into the plant canopy most of the incoming solar radiation. ${ }^{10,12}$

Anikwe et al. concluded that black plastic mulching enhanced growth and yield of the plants in the arid lands. These results are also in line with the results reported by Khurshid et al., ${ }^{12}$ that mulching increased soil porosity and reduced soil compaction. Also, these results are in agreement with those of Sarkar et al., ${ }^{13}$ whom concluded that mulching (especially black plastic mulch) reduced leaching of nutrients, reduced weed problems, reduced evaporation of soil water and increased water use efficiency. They also cleared that plastic mulch helped maintain optimum soil moisture and promoted excellent crop growth throughout the growing season. Moreover, Mulching 
increased growth and fruit yield of tomato through modification of the crop growing environment by reducing weed infestation, soil moisture depletion and ameliorating soil temperatures ${ }^{14}$ on tomato.

Eissa, (2002) showed that strawberry plants grown in row covered with plastic mulch (black, silver and control) had significant increase in its fruit TSS as Compared with plants grown in bare soil. He added that Silver plastic mulch was superior in this regard to the other treatments. Meanwhile Ekinci et al., ${ }^{15}$ mentioned that different mulches applications (clear and black) did not affect in total soluble solids of watermelon fruit. ${ }^{15}$ found that there were no significant differences in term of titratable acidity in melon fruits among the applications of polyethylene mulch (Clear and black). While ${ }^{16}$ illustrated that using plastic mulch color, red and red over black mulches showed the highest values of titratable acidity in strawberry fruits compared with other mulch color treatments (Black and control). sreported that black mulches produced higher vitamin $\mathrm{C}$ content in chilli plants. Moreover, ${ }^{18}$ who deduce that covering the rows with black polyethylene mulch or red color gave the highest value of vitamin $\mathrm{c}$ in pepper fruits when compared with fruits of the plants, which grown with clear polyethylene mulch. While, the lowest concentration of vitamin $\mathrm{c}$ was obtained from plants grown in the bare soil. He also added that the improvement in fruit quality of pepper by mulching treatments may be due to its promotion effect in plant growth and metabolic process, which reflected on increasing chemical composition as vitamin $\mathrm{C}$ in fruits. Same finding were noticed ${ }^{19}$ showed that an increased amount of vitamin $\mathrm{C}$ in chilli fruit was observed in all the mulch treated plants (blue, and black) compared to control. Ekinci et al., ${ }^{15}$ reported that total sugar content in fruit of melon significant increase in plants by the treatment with plastic mulches (black and clear) compared to control. Also ${ }^{16}$ who found that the application with polyethylene mulching (red, black and red on black) as a row covering significantly increased total sugar content in strawberry fruits. Same results were obtained by Parmar et al, ${ }^{10}$ who reported that using polyethylene mulching (control, silver on black, yellow on black, red on black white and white on black) enhanced the total sugar content in Watermelon fruits.

Root of plants grown with white and yellow plastic mulch had significantly higher concentrations of B-carotene than did those grown with the other colors. Both the white and yellow surfaces reflected more photosynthetic light and a lower FR/R ratio than the blue, green, and red surfaces. Other spectral differences in reflection from white and yellow apparently had less influence than PPF and FR/R ratio on accumulation of B-carotene in the carrot roots. Antonious and Kasperbauer found that when the carrot of effect grown in field plot that were covered with different panels that reflected various combinations of far-red (FR), red (R) and blue light (BL) to the growing leaves. ${ }^{17}$ found that fruit dry matter was increased due to polyethylene mulch. They deduced that the favorable effect on cucumber fruit quality owing to black and clear polyethylene mulches. $\mathrm{s}^{18}$ found that the dry matter (\%) of fruits was unaffected by the polyethylene mulching on cucumber. Also ${ }^{15}$ reported that, There were no significant differences in term of dry matter in fruit of water melon among polyethylene mulches applications. Therefore, the objective of this study was conducted to compare the effect of different mulching materials on the growth, fruit yield and their quality of husk tomato grown in open field.

\section{Materials and methods}

The present study was carried out during the two successive seasons of 2011/2012 and 2012/2013 on husk tomato plant (Physalis pubescens L.) cv. (local variety). Plants were grown in a private farm located at Shebeen El-Qanatir city, El-Qaliubiya governorate, Egypt. The soil type is clay loam. Soil samples were taken before planting for physical and chemical analysis according to (Jackson 1973). ${ }^{19}$ Its physical and chemical analysis is shown in Table 1. Soil temperatures were measured at $10 \mathrm{~cm}$ depth for all treatments using soil thermometer at 2:30pm on second day after irrigation (Table 2). This experiment aimed to study the effect of polyethylene mulching on growth, yield and fruit quality of husk tomato plants. Two different colors of polyethylene mulch i.e., black and double face (white on black) of plastic films, 45 micron thickness and $120 \mathrm{~cm}$ width were used. Polyethylene mulches were installed manually, stretched tightly on soil surface after 45 days from transplanting, whereas, the white side of the double face of plastic film was above the soil surface while the black side was below. A bare soil plot of equal area was also maintained with raised beds un-mulched as a control. Seeds were sown in seedbeds on July $5^{\text {th }}$ in both seasons of 2011/2012 and $2012 / 2013$. Seedlings were transplanted after 40days from sowing in the open field. Surface irrigation by furrows was applied and the others agricultural practices took place according to the recommendation of the Ministry of Agricultural. The area unit of each replicate was $15 \mathrm{~m}^{2}$ included three rows; each row was five meters long and one meter width. Seedlings were transplanted $80 \mathrm{~cm}$ apart on the row.

Table I Physical and chemical analysis of the experimental soil during $2011 / 2012$ and 20I2/20I3 seasons

\begin{tabular}{|c|c|c|c|c|c|c|c|c|c|c|c|c|c|}
\hline \multirow[t]{3}{*}{ Seasons } & \multicolumn{4}{|c|}{ Physical properties } & \multicolumn{9}{|c|}{ Chemical properties } \\
\hline & \multirow[t]{2}{*}{ Sand \% } & \multirow[t]{2}{*}{ Silt \% } & \multirow[t]{2}{*}{ Clay \% } & \multirow[t]{2}{*}{ Texture } & \multirow[t]{2}{*}{$\begin{array}{l}\mathrm{EC} \\
\mathrm{ds} / \mathrm{m}\end{array}$} & \multirow[t]{2}{*}{ PH } & \multicolumn{4}{|c|}{$\begin{array}{l}\text { Soluble cation (meq } \\
\left.\left.\right|^{-1}\right)\end{array}$} & \multicolumn{3}{|c|}{$\begin{array}{l}\text { Soluble anion (meq } \\
\left.I^{-1}\right)\end{array}$} \\
\hline & & & & & & & $\mathrm{Na}^{+}$ & $\mathrm{Ca}^{++}$ & $\mathbf{M g}^{+}$ & $\mathbf{K}^{+}$ & Hco3- & $\mathrm{Cl}^{-}$ & so4 \\
\hline $2011 / 2012$ & 41.8 & 28.7 & 29.5 & Clay loam & 0.25 & 7.99 & 0.72 & I & 0.5 & 0.09 & I & I & 0.31 \\
\hline $2012 / 2013$ & 43.8 & 27.6 & 28.6 & Clay loam & 0.24 & 7.97 & 0.69 & I & 0.5 & 0.08 & I & I & 0.27 \\
\hline
\end{tabular}


Table 2 Average degree of soil temperature $(\mathrm{oC})$ at $10 \mathrm{~cm}$ depth

\begin{tabular}{|c|c|c|c|c|c|c|}
\hline \multirow{2}{*}{$\begin{array}{l}\text { Treatments } \\
\text { Seasons/ } \\
\text { months }\end{array}$} & \multicolumn{2}{|c|}{ Control (No Mulch) } & \multicolumn{2}{|l|}{ Black Mulch } & \multicolumn{2}{|c|}{ White \& Black Mulch } \\
\hline & $\begin{array}{l}\text { First year } \\
(20|1 / 20| 2)\end{array}$ & $\begin{array}{l}\text { Second year } \\
(20|2 / 20| 3)\end{array}$ & $\begin{array}{l}\text { First year } \\
(20 \mid I / 2012)\end{array}$ & $\begin{array}{l}\text { Second year } \\
(20 \mid 2 / 2013)\end{array}$ & $\begin{array}{l}\text { First year } \\
(201 / / 2012)\end{array}$ & $\begin{array}{l}\text { Second year } \\
(2012 / 2013)\end{array}$ \\
\hline September & 21.9 & 22.7 & 24.1 & 25.5 & 22 & 23.3 \\
\hline October & 15.9 & 16.4 & 17.5 & 19.4 & 16.1 & 17.5 \\
\hline November & 12.9 & 13.1 & $14 . \mid$ & 15.8 & 13.6 & 14.1 \\
\hline December & 10.5 & 11.9 & 13.8 & $\mid 4.4$ & 12.8 & 12.5 \\
\hline January & 11.6 & 12.7 & 13.1 & 15.3 & 12.2 & 13.9 \\
\hline February & 13.1 & 13.5 & 15.2 & 15.9 & 14.2 & 14.9 \\
\hline March & 16.1 & 17.2 & 17.2 & 18.7 & 16.9 & 17.9 \\
\hline April & 18.2 & 18.8 & 19.1 & 19.9 & 18.9 & 19.2 \\
\hline May & 20.9 & 21.7 & 24.1 & 25.5 & 21 & 22.3 \\
\hline
\end{tabular}

\section{Data recorded}

\section{Vegetative characteristics}

Physical parameters: After five months from transplanting the following data were determined:

i. Plant height $(\mathrm{cm})$ was estimated from cotyledons level to the main shoot tip using miter trip.

ii. Number of branches/plant was counted manually.

iii. Leaf area of the 5th leaf from the shoot tip (measured by Li-300 leaf area meter produced by Li-Cor, Pinclivania).

iv. Stem diameter $(\mathrm{cm})$ was calculated by Vernier Caliper.

Chemical parameters: Total chlorophyll content was determined by the spectrophotometric method described by Hipkins et al. ${ }^{20}$

Fruit characteristics Physical parameters: A random sample of 20 fruits from each plot was randomly chosen to determination of:

i. Average fruit weight (g) was measured by a digital balance.

ii. Fruit size $\left(\mathrm{cm}^{3}\right)$ was measured by measuring the water volume displaced by immersing the fruits in graduated Jar filled with water.

iii. Fruit diameter $(\mathrm{cm})$ was estimated by Vernier Caliper.

iv. Fruit firmness $\left(\mathrm{kg} / \mathrm{cm}^{2}\right)$ was measured using a pressure tester (Digital force-Gouge Model FGV-0.5A to FGV-100A. shimpo instruments).

\section{Chemical parameters:}

i. Total soluble solids (TSS \%) was determined by hand Refractometer according to A.O.A.C. (2000). ${ }^{21}$

ii. Total titratable acidity (g citric/100 g fresh weight) was determined by titration with $0.01 \mathrm{~N} \mathrm{NaOH}$ using phenolphthalein as indicator according to A.O.A.C (2000). ${ }^{21}$

iii. Vitamin C (Ascorbic acid) (mg/100 g f.w.) was estimated by titration with 2,6-dichlorophenolindophenol dye according to A.O.A.C. (2000). ${ }^{21}$

iv. Total sugars: Total sugars content in the curd were determined as (g/100g dry weight) according to Smith et al., (1956).

v. Total carotenoids (mg/100g f.w.) were determined using spectrophotometer and calculated by using wattstein formula as described in Hipkins and Baker (1986). ${ }^{20}$

vi. Fruit dry matter (\%): Fruit samples were dried in an oven at 70 $0 \mathrm{C}$ till constant weight and the dry matter calculated according to the following formula: Dry matter $(\%)=$ Dry weight/Fresh weight $* 100$.

\section{Yield parameters}

i. Number of fruits per plant was counted during the whole period of harvesting in three plants as a sample. Early yield per plot $(\mathrm{Kg})$ : Was calculated as the total fresh weight of fruits harvested from the first fourth pickings.

ii. Total yield per plant $(\mathrm{kg})$ : Was calculated as weight of all harvested fruit per plant throughout the whole season.

iii. Total yield per plot $(\mathrm{Kg})$ : Was calculated as weight of all harvested fruit per plot throughout the whole season.

\section{Statistical analysis}

All experiments were statistically analyzed in a complete randomized design with three replicates. Each replicate consisted of six plants. Obtained data were subjected to the analysis of variance procedure and means were compared by L.S.D. method at $5 \%$ level of significant according to Snedecor and Cochran (1982). ${ }^{22}$

\section{Results and discussion}

\section{Vegetative characteristics}

Physical parameter: Data about the physical parameters of vegetative characters are register in Figure 1(A-D). The results clarified the presence significant increments on plant height, stem diameter, number of branches per plant and leaf area of husk tomato plants as a result of applications of different polyethylene types i.e., black and (white on black). The highest value was recorded with (white on black) followed by black mulching. However the lowest value of these parameters were obtained with the plants grown in bare soil (control). The same trends were obtained in both seasons 
of 2011/2012 and 2012/2013. The increments in vegetative growth parameters of husk tomato plants as a result of mulch treatments may be due to that plastic mulches directly affect the microclimate around the plant by modifying the radiation budget of the surface and decreasing the soil water loss ${ }^{7}$ resulting in more uniform soil moisture. The soil temperature in the planting bed is raised, promoting faster crop development and earlier harvest. ${ }^{8}$ Mulching decreases the fluctuations in temperature in the first $20-30 \mathrm{~cm}$ depth in soils and promotes root development, reduces vegetative competition in the rooting zone, reduces fertilizer leaching and soil compaction, and the vegetable productions are cleaner since no soil is splashed onto the plants or fruits ${ }^{9}$ From another point of view, the increments of husk tomato growth regarding to polyethylene mulching treatments may be due to the increase of light from reflectivity from the reflective mulch surface allows greater photosynthetic activity of the plants, ${ }^{23}$ On the other hand, the primary purpose for using mulches is that black and (white on black) mulches will reduce light penetration to the soil. Weeds cannot generally survive under such mulch. Excess water runs off the impervious mulch. Fertilizer beneath the mulch is not lost by leaching, so that fertilizers are optimally used and not wasted. The soil under plastic mulch remains loose, friable and wellaerated. Roots have access to adequate oxygen and microbial activity is enhanced resulting in encouraged of plant growth. ${ }^{10}$ White, (white on black) reflective mulches can result in a slight increase or even a slight decrease in soil temperature compared to bare soil, tending to minimize changes in soil temperature, because they reflect back into the plant canopy most of the incoming solar radiation. ${ }^{9,11}$ Data also
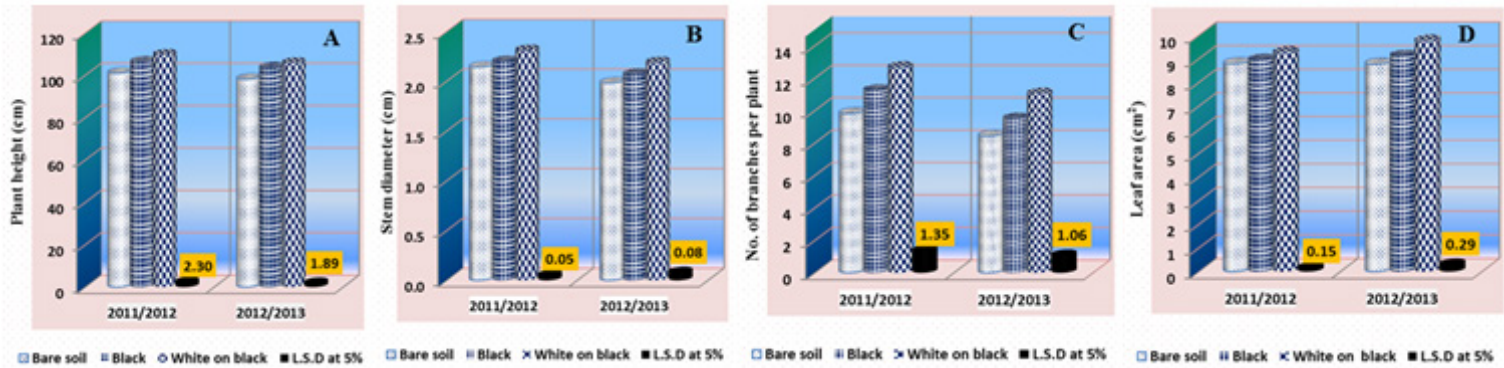

Figure I Effect of polyethylene mulching types on plant height (A), stem diameter (B), number of branches per plant (C) and leaf area (D) of husk tomato plant during $2011 / 2012$ and 2012/2013 seasons.

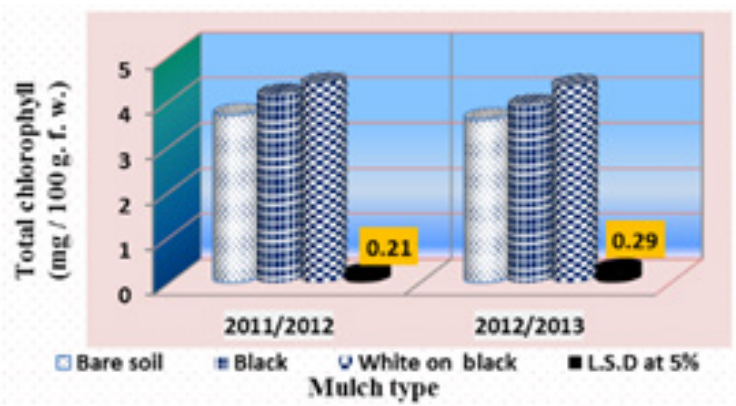

Figure 2 Effect of polyethylene mulching types on total chlorophyll of husk tomato leaves during $2011 / 2012$ and $2012 / 2013$ seasons.

\section{Fruit characteristics}

physical parameters: The effect of polyethylene mulching on the physical parameters of fruit characteristics is listed in Figure 3(A-D). The results indicated that average fruit weight, size, diameter and firmness of husk tomato plants significantly increased as a result of mulching rows with polyethylene. It was noticed that the grown cleared that using polyethylene type (white on black) obtained the superior effect than black type. Because of white plastic mulch usually generates cooler soil temperatures than black plastic. ${ }^{24}$ Also white plastic is preferred during the summer growing season in warmer regions compared to black because it can maintain soil moisture while providing cooler temperatures. ${ }^{11}$

Chemical parameter: Data presented in Figure 2 clearly revealed that total chlorophyll content in leaves of husk tomato plants significantly increased due to the applications of polyethylene mulching either black or (white on black) colors . Using (white on black) plastic as a row mulching obtained the highest value of this parameter followed by the black type. On the other side, growing husk tomato plants in bare soil (control) gave the lowest value.The favorable effect of polyethylene mulching on photosynthetic pigments may be due to the hypothesis that Chlorophyll a is an essential compound of the light reaction of photosynthesis, whereas Chlorophyll b function is as light harvesting pigment whose absorbed light energy which passed on to Chlorophyll a. ${ }^{25}$ So, the plants grown on the mulch should increase Chlorophyll a to absorb the greatest amount of light which reflected in high dry matter content. Such response to a spectral balance of up warded reflected light from variously colored mulch is consistent with development responses to shift wave length balance of light due to reflecting from comparing plants. ${ }^{26}$ Moreover, the increment of total chlorophyll according to using (white on black) mulch may be due to that plastic mulching increase the soil microbial population and increased nitrogen absorption and consequently increased chlorophyll content of the plant leaves as mentioned by (Eissa, 2002). ${ }^{27}$ 
matter \%, the results In Figures 4 and Figure 5 recorded significant increase in the previous parameters except the total acidity and dry matter $\%$ which did not affect. Also, the reflection of more light onto the tomato shoot by plastic is known to increase transpiration rate, amount of photosynthesis available to fruits and sugar: acid ratio as reported by Dorais. ${ }^{30}$ Moreover, Plastic mulches concentrate carbon dioxide around the plant canopy as the planting holes acts as vents for carbon dioxide escaping from beneath the mulch. This relatively elevated carbon dioxide concentration might have accounted for the increased total soluble solids ${ }^{22}$ On the other side, the improvement in vitamin $\mathrm{C}$ (ascorbic acid), total sugar and total carotenoids content in husk tomato fruits according to polyethylene treatments may be due to the promotion effect in plant growth and metabolic process, which reflected on increasing chemical composition. Our results are in agreement with ${ }^{28}$ on pepper.

Yield parameters: Data recorded in Figure 6(A-D) showed the effect of polyethylene mulching i.e. control (bare soil), black and (white on black) on yield and its components of husk tomato plants during the two growing seasons of 2011-2012 and 2012-2013. The results clear that both treatments of polyethylene mulching significantly raised the number of fruit per plant, early yield per plot and total yield per plant and plot compare to the control treatments (bare soil). On the other side covering the rows with (white on black) polyethylene gave the highest early yield, while the control one obtained the lowest value in the two growing seasons of 2011-2012 and 2012-2013. The promotion effect of polyethylene mulch on the yield characters of husk tomato plants including the number of fruits per plant, early yield per plot, total yield per plant and plot may be due to low weed population, causing a reduction in competition for nutrient and partly for a better water availability due to moisture conservation by mulching. ${ }^{31}$ Moreover, Mulching increased growth and fruit yield of tomato through modification of the crop growing environment by reducing weed infestation, soil moisture depletion and ameliorating soil temperatures. ${ }^{14}$ On the other hand, Singh et al. reported that mulch could improve leaf photosynthetic capacity beside the role of polyethylene for enhanced root growth, as well as, absorption of each of water and nutrients and thereby, enhanced metabolic activities within plant during the period of growth and reproduction process, which possessed much shoot number per plant and width leaf area with high leaf chlorophyll content as mentioned before that induced more photosynthetic rates. This in turn built high yield of carbohydrates which gave rise to more cell division and enlargement inducing more vegetative vigorous plants, this reflect to produce more total yield as mentioned by Our results are in agreement with those results obtained with $^{28}$ on pepper and ${ }^{32}$ on tomato. ${ }^{33-37}$
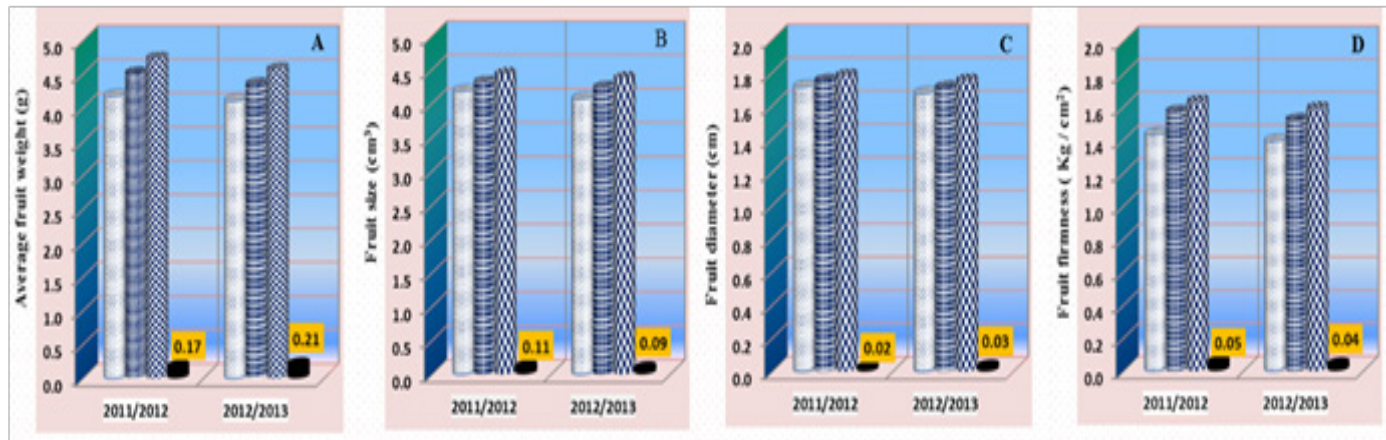

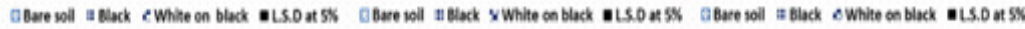

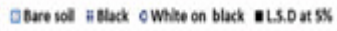

Figure 3 Effect of polyethylene mulching types on average fruit weight (A), size (B), diameter (C) and firmness (D) of husk tomato fruit during $201 \mathrm{I} / 2012$ and $2012 / 2013$ seasons.
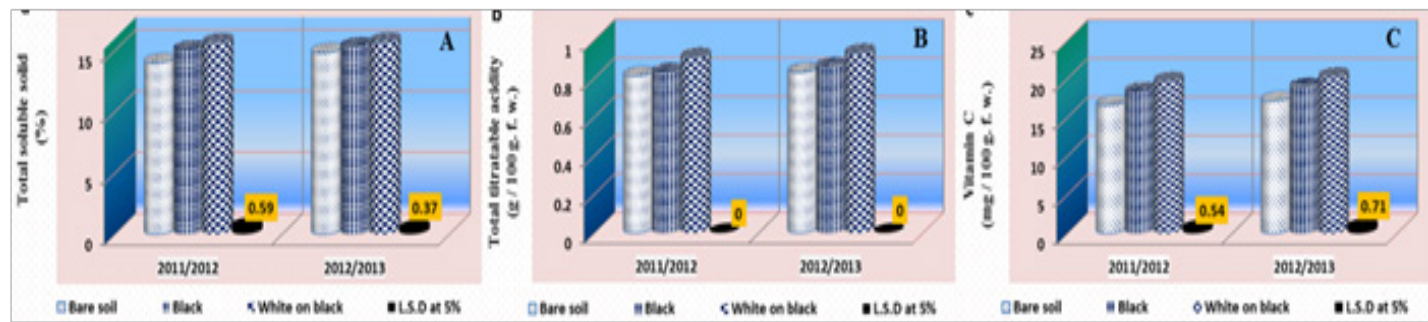

Figure 4 Effect of polyethylene mulching types on total soluble solid (T.S.S.) (A), total titratable acidity (B) and Vitamin C (ascorbic acid) (C) of husk tomato fruits during $2011 / 2012$ and $2012 / 2013$ seasons.
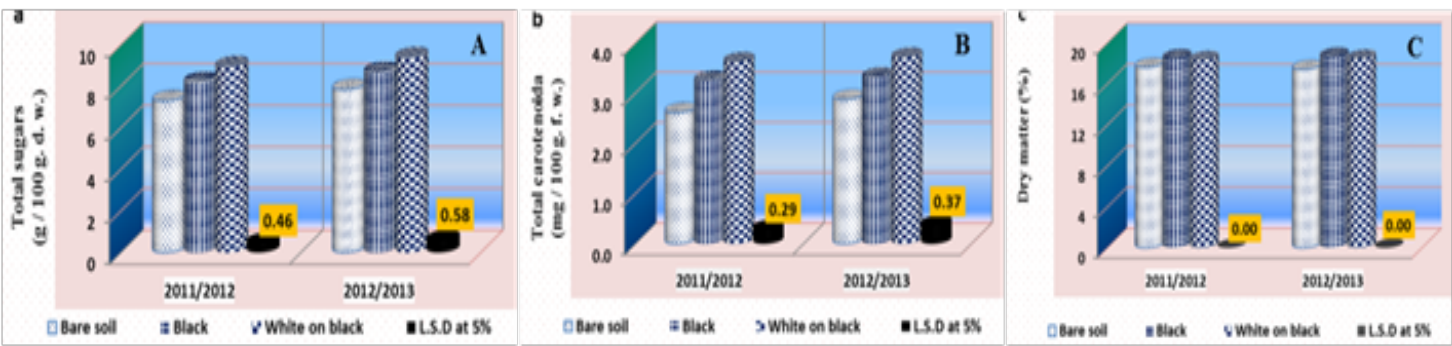

Figure 5 Effect of polyethylene mulching types on total sugars (A), carotenoids (B) and dry matter (C) of husk tomato fruits during 20II/20I2 and 20I2/20I3 seasons. 

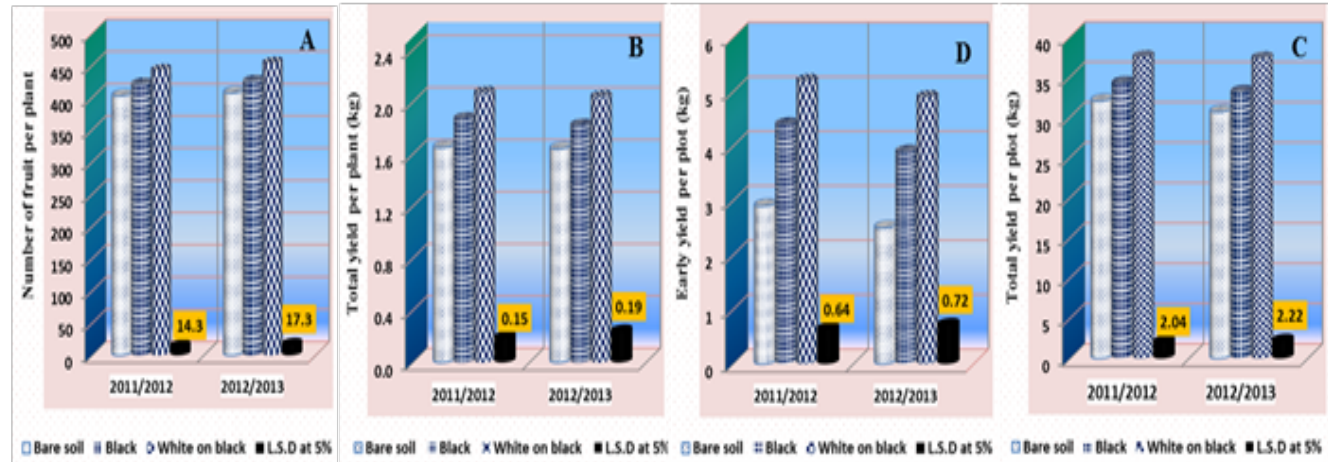

Figure 6 Effect of polyethylene mulching types on number of fruits per plant (A), total yield per plant (B), early yield per plot (C) and total yield per plot (D) of husk tomato during $2011 / 2012$ and 2012/2013 seasons.

\section{Recommendations}

Mulching treatments increased fruit quantity and quality, early yield, and total yield. Mulching treatment of double faces (white on black) was more effective than the black mulch.

\section{Acknowledgements}

Authors are grateful to Al-Azhar University, Faculty of Agriculture, Horticulture department, Government of Egypt for supporting this research project to carry out this work. The authors express their gratitude to, Prof. Dr. Adel Abdelaziz Mohamed and Dr. Mostafa Zaki Ahmed Sultan at Horticulture Department, Faculty of Agriculture, Al-Azhar University for their Support, constructive suggestions, supervision, advice, sincere help and valuable guidance throughout the course of this study.

\section{Conflict of interest}

The author declares no conflict of interest.

\section{References}

1. El Sheikha AF. Technological, chemical and microbiological studies on some packed foods. Fac. Agric Minufiya Univ Master Sci Egypt; 2004. $174 \mathrm{p}$.

2. Goda Y, Abd El-Rehim AS, Mohamed AA, et al. Effect of shoot pruning on growth, yield and fruit quality of husk tomato (Physalis pubescens L). Journal of American Science. 2014;10(1):5-10.

3. El Sheikha AF, Zaki MS, Bakr AA, et al. Biochemical and sensory quality of Physalis (Physalis pubes-cens L) juice. J Food Proc Preserv. 2010;34:541-555.

4. Mustafa AMM. Effect of nitrogen, potassium fertilization and their interactions on yield and quality of husk tomato. M Sc Thesis Fac Agric Alexandria Univ; 2009.

5. Tripathi RP, Katiyar TPS. Effect of mulches on the thermal regime of soil. Soil Till Res. 1984;4(4):381-390.

6. Kasirajan S, Ngouajio M. Polyethylene and biodegradable mulches for agricultural applications. Agr Sustain Dev. 2012;32(2):501-529.

7. Liakatas A, Clark JA, Monteith JL. Measurements of the heat balance under plastic mulches part I. Radiation balance and soil heat flux. Agri For Meteorology. 1986;36(3):227-239.

8. Lamont WJ. Plastic mulches for the production of vegetable crops. Hort Technology. 1993;3(1):35-39.
9. Ham JM, Kluitenberg GJ, Lamont WJ. Optical properties of plastic mulches affect the field temperature regime. J Amer Soc Hort Sci. 1993;118(2):188-193.

10. Parmar HN, Polara ND, Viradiya RR. Effect of Mulching Material on Growth, Yield and Quality of Watermelon (Citrullus Lanatus Thunb) $\mathrm{CV}$ Kiran. Universal J of Agricultural Research. 2013;1(2):30-37.

11. Csizinszky AA, Schuster DJ, Kring JB. Evaluation of color mulches and oil sprays for yield and for the control of silver leaf whitefly, Bemisia argentifolii (Bellows and Perring) on tomatoes. Crop Prot. 1997;16(5):475481 .

12. Glab T, Kulig B. Effect of mulch and tillage system on soil porosity under wheat (Triticum aestivum). Soil and Tillage Res. 2008;99(2):169-178.

13. Sarkar S, Singh SR. Interactive effect of tillage depth and mulch on soil temperature, productivity and water use pattern of rainfed barley (Hordium vulgare L). Soil and Tillage Res. 2007;92(1-2):79-86.

14. Awodoyin RO, Ogbeide FI, Oluwole O. Effects of three mulch types on the growth and yield of tomato (Lycopersicon esculentum Mill) and weed suppression in ibadan, rainforest-savanna transition Zone of Nigeria. Tropical Agricultural Research \& Extension. 2007;10:53-60.

15. Ekinci M, Dursun A. Effects of different mulch materials on plant growth, some quality parameters and yield in melon (cucumis melo 1) cultivars in high altitude environmental condition. Pak J Bot. 2009;41(4):18911901.

16. Abou El-Yazied A, Mady MA. Plastic mulch color and potassium foliar application affect growth and productivity of strawberry (Fragaria $\mathrm{X}$ ananassa Duch). Journal of Applied Sciences Research. 2012;8(2):12271239

17. Cevik B, Kanber R, Koksal H, et al. Effect of different soil mulch materials and irrigation lever on yield, quality and evapotranspiration of cucumbers grown under glass house conditions. Doga Turk Tarm Ve Ormancihk Dergisi. 1992;16:581-591.

18. El-Sanafawi EMM. The effect of some culture treatments on growth and productivity of cucumber under greenhouse conditions. Ph D Thesis Vegetable Crops Hort Sci Dept Menofiya univ Shebin El-Kom; 2000.

19. Jackson ML. Soil Chemical Analysis. New Jersy Prentice Hall Inc; 1973. $448 \mathrm{p}$.

20. Hipkins MF, Baker NR. Photosynthesis energy transduction. In Hipkins MF, et al. editors. Spectroscopy. UK: IRL Oxford; 1986. p. 51-105.

21. Gaithersburg MD, AOAC. Official methods of analysis of A.O.A.C. (Association of Official Analytical Chemists) International. 17th ed. AOAC International; 2000. 
22. Sanders DC, Howell TA, Hile MMS, et al. Yield and quality of processing tomatoes in response to irrigation rate and schedule. J Am Soc Hort Sci. 1989;114:904-908.

23. Mahmoudpour MA, Stapleton JJ. Influence of sprayable mulch color on yield of eggplant (Solanum melongena L. cv. Millionaire). Sci Hortic. 1997;70(4):331-338

24. Diaz-Perez JC, Batal KD. Soil-plant-water relationships-colored plastic film mulches affect tomato growth and yield via changes in root-zone temperature. Journal of the American Society for Horticultural Science. 2002;127:127-135.

25. Dennis DT, Turpin DH. Plant physiology, biochemistry and molecular biology. Longman Scientific and Technical BS. 1990;23:213-216.

26. Kasperbauer MJ. Far-red light reflection from green leaves and effects on phytochrome-medicated assimiale partitioning under field conditions. Plants Phsiol. 1987;85(2):350-354.

27. Eissa NMH. Effect of some plasticulture and fertigation treatments on productivity and fruit quality of strawberry. Ph D Thesis Fac Agric Zagazig Univ; 2002.

28. Moursi MH. Studies on some factors affecting the characteristics and production in pepper plants. Ph D Thesis Fac Agric Minufiya Univ; 2003.

29. Manrique LA. Mulching in potato systems in the tropics. Journal of plant nutrition. 1995;18(4):593-616.
30. Dorais M, Papadopoulos AP, Gosselin A. Influence of electric conductivity management on greenhouse tomato yield and fruit quality. Agronomie. 2001;21(4):367-383.

31. Shrivastava RK, Parikh MM, Sawani NG, et al. Effect of drip irrigation and mulching on tomato yield. Agric Water Manage. 1994;25:179-184.

32. Rajablariani HR, Hassankhan F, Rafezi R. Effect of colored plastic mulches on yield of tomato and weed biomass. International Journal of Environmental Science and Development. 2012;3(6):590-593.

33. Panchal SC, Bhatnagar R, Momin RA, et al. Influence of cultural practices on quality of green and red chilli (Capsicum annum L.) fruit. Indian $J$ Agric Biochem. 2001;14:21-24.

34. Ashrafuzzaman M, Halim MA, Ismail MR, et al. Effect of Plastic mulch on growth and Yield of Chilli (Capsicum annuum L). Braz Arch Biol Technol. 2011;54(2):321-330.

35. Antonious GF, Kasperbauer MJ. Color of light reflected to leaves modifies nutrient content of carrot roots. Published in crop Sci. 2002;42(4):12111216.

36. Michel D, Smith F, Hamilton JK, et al. Colorimetric method for determination of sugars and related substance. Anal Chem. 1956;28(3):350-356.

37. Snedecor GW, Cochran WG. Statistical Methods. 6th ed. Iowa State Univ. USA: Press Ames Iowa; 1982. 